\title{
African Women in the Hebrew Bible: A Socio- economic and African Hermeneutical Reading
}

Funlọla O. OLọjẹde (STELlenbosch University)

\begin{abstract}
In conversation with David Adamo's Africa in the Bible approach, which investigates the presence of Africa and Africans in Scriptures, this article conducts a synoptic search of the named and unnamed "African" women of the Torah and Nebiim with the aim of probing their socio-economic status. We ask, to what extent does a socioeconomic reading of the portraits of these women - from Hagar to the Queen of Sheba - afford us a glance into the lives of women in antiquity in the geographical location called Africa today, many of whom seemed to enjoy a great degree of social and economic independence? The social identity and status of these women may help to counteract some of the modern images of African women as victims of patriarchy under male power. The implications of the findings for African biblical hermeneutics of which Adamo is one of the foremost proponents cannot be over-emphasised.
\end{abstract}

\section{A INTRODUCTION}

In contemporary times and recent history, African women are regarded as victims of patriarchy, gender inequality and hegemonic masculinities sidelined, oppressed, impoverished and violated in diverse ways. Searching aspects of the Old Testament text for images of females classifiable as "African" in terms of their geographical origin in the ancient world, this essay debunks the image of the modern African woman as victim and underdog by arguing that the images of her biblical ancestresses showed many independent women who exercised agency and were leaders in their own right. It therefore draws on David Adamo's Africa-in-the-Bible approach to probe the roles, statuses and characters of "African" women in the Torah and Nebiim.

\section{Adamo's Africa in the Bible approach}

David Tuesday Adamo is well-known for his Africa-in-the-Bible approach, which investigates the presence of Africa and Africans in the Bible. ${ }^{1}$ In his

* Submitted: 29/07/2021; peer-reviewed: 14/09/2021; accepted: 15/09/2021. Funlọla O. Olojẹde, "African Women in the Hebrew Bible: A Socio-economic and African Hermeneutical Reading," Old Testament Essays 34 no. 2 (2021): 610 - 627. DOI: https://doi.org/10.17159/2312-3621/2021/v34n2a17.

1 Adamo has published several volumes and articles that underscore this approach including Africa and the Africans in the Old Testament (Eugene: Wipf and Stock, 2001); Exploration in African Biblical Studies (Eugene: Wipf and Stock, 2001); 
Africa and the Africans in the Old Testament, Adamo notes that classical Eurocentric interpretations of the Bible have tried to de-Africanise the Bible either by denying the presence of Africans in the Bible or by minimising "their influence and worth." ${ }^{2} \mathrm{He}$ therefore examines the references to Africa and Africans in the Old Testament as well as "the role and contributions of Africa and Africans in the political, religious and economic history of ancient Israel." 3 Adamo's study not only highlights the various terms used for places that fell within the geographical location known as Africa today, but it also outlines the various references to Africa and Africans in the Torah, Nebiim and Kethuvim, while taking into account the major timelines in Israel's ancient history. In line with Adamo's outline therefore, this study conducts a synoptic examination of the named and unnamed African ${ }^{4}$ women in the Old Testament from the Torah and the Nebiim.

\section{B A SYNOPTIC SEARCH OF NAMED AND UNNAMED AFRICAN WOMEN IN THE TORAH AND NEBIIM}

This section presents a synoptic outline of women of African descent in the Old Testament namely in the Torah and Nebiim. It draws on textual and literary evidence to discern the economic and social status of these female characters. Whereas some of the women are named, many are unnamed or identified in relation to their husbands or fathers. The discussion will follow the order of the appearance of these women in the canonical text.

\section{African women in the Torah}

References to Africa and Africans are scattered all over the Torah especially references to Egypt or Egyptians and Cush or Cushites, ${ }^{5}$ which imply that women are invariably included in these references. This section, therefore, investigates the presence of African women in the Torah.

\footnotetext{
"Reading Jeremiah 13:23 in an African Context," JSem 23/4 (2014): 500-530; "The African Wife of Jeroboam," Theologia Viatorum 37/2 (2013): 71-89; "The Portrayal of Africa and Africans in the Book of Jeremiah," In die Skriflig 51/1 (2018): 1-9. This essay is a tribute to Prof Adamo's foresight and relentless effort to foreground Africa and Africans in his biblical scholarship. I wish to thank him for his pioneering works and his positive contributions to the study of the biblical text in Africa.

2 Adamo, African and the Africans, 2.

3 Ibid., 5.

4 By African, we do not of course mean to say that the term Africa is used in the Scriptures but we refer to those people that emanated from parts of the geographical space that is today known as the African continent.

5 Adamo, African and the Africans, 51-61. Adamo notes that the term Kush was used by Egyptians to refer to their southern neighbours and subsequently by Assyrians and Hebrews to refer to dark skinned people in Africa and amongst their own people, Adamo, African and the Africans, 61.
} 
1a Hagar, the Egyptian slave woman

The first clear mention of a named woman of African origin in the Old Testament is in Gen 16 where the reader encounters Hagar, the Egyptian maid of Sarah (Sarai), the wife of Abraham (Abram). However, there is an indication of the presence of Egyptian women earlier in the text in Gen 12:16 where Abraham is said to acquire, among other "possessions," maidservants while sojourning in Egypt. It is presumed by some commentators that Hagar was probably one of those maidservants, who was acquired personally by Sarah while the latter was abducted by the Pharaoh. ${ }^{6}$

Hagar is repeatedly called an Egyptian in the book of Genesis where her story features in the Old Testament (Gen 16:1, 3; 21:9; 25:12), which means that she was of African descent. ${ }^{7}$ Equally significant is the fact that she is also called maidservant, handmaid or slave woman. This designation points to her socio-economic status; slaves were on the lowest rung of the social ladder in the ancient world and female slaves were the lowest of the low. A slave had no own property or asset, for both the slave and everything s/he had belonged to the owner. For several years, then, Hagar served in the household of Sarah and Abraham as a handmaid before her mistress advanced a plot to upgrade her from the status of a slave (or bondwoman) to that of a wife (Gen 16:3). From that arranged marriage of convenience, which she was to bear children for Sarah, Ishmael was produced. The relationship between Hagar and Sarah got sour after the union and she fled from Hagar while still pregnant with Ishmael. However, with her encounter with the angel of the Lord in the wilderness, she returned to her mistress gave birth to her son Ishmael who was named by the angel of the Lord while in the womb (Gen 16:7-14). It has already been observed that Hagar, the Egyptian maid, was the first woman in the Scriptures to have a personal divine encounter and hers was "the first of the annunciation scenes in Genesis." ${ }^{\prime 8}$ Not only that, she was the first and only woman in the Old Testament to give God a name, and this, after God himself had called her by name.

6 Susan M. Pigott, "Hagar: The M/Other Matriarch," 115/4 (2018): 515. Yoo notes that, "In the Genesis Apocryphon, when Pharaoh restores Sarah to Abraham, he bestows gifts on Sarah (and not on Abraham; cf. Gen 12:16) and includes Hagar among these gifts (1QapGen ar 20.30-32)"; Philip Y. Yoo "Hagar the Egyptian: Wife, Handmaid, and Concubine," CBQ 78 (2016): 216.

7 It is striking that Adamo fails to mention this remarkable woman whose significant presence in the Old Testament would later pose a permanent threat to the Abrahamic covenant (cf. Gen 21:9-21; Gal 4:24-25) in his debut volume, Africa and the Africans. One must concede though that he acknowledges that, "The research into the role and identification of African women in the Bible is relatively new." Adamo, African and the Africans, 73.

8 Susan Niditch, "Genesis," in Women's Bible Commentary (Twentieth Anniversary Edition; ed. Carol A. Newsom, Sharon H. Ringe and Jacqueline E. Lapsley; Louisville: Westminster John Knox, 2012), 35. 
What is remarkable here is the fluctuation in the social status of Hagar, who started out as a handmaid in the household and transitioned to the status of a wife and mother but became relegated again to the status of a bondwoman and to desert life with her son (Gen 21:10, 14-21). She ended up as an outcast in the desert of Paran - no longer a slave-woman but a socially and economically destroyed vagabond. In the end, Hagar's antithetical role in the redemption plan is explicated in Galatians' allegory of two covenants (Gal $4: 22-25){ }^{9}$

\section{1b Unnamed Wife of Potiphar}

The second African female character of note in the book of Genesis is the unnamed wife of Potiphar, an officer of Pharaoh and a captain of the guard (Gen 39:1-18). Not much is known about Potiphar except that he was a highranking officer in Pharaoh's army, which places him and his wife in the upper echelon of society. When Joseph was sold into slavery by his brothers, he landed in the house of Potiphar, who saw a leader in him and made him chief of his domestic staff. However, Potiphar was not the only one who saw something special about Joseph; his wife also did. ${ }^{10}$ Potiphar's wife saw in Joseph an object of desire and sought to lie with him. Joseph resisted the advances of his master's wife, regarding the proposition as "great wickedness" (Gen 39:9). When Potiphar's wife could not have her way with Joseph, she publicly accused him of attempted rape and Joseph was thrown into jail without trial.

Niditch sees the image of Potiphar's wife in Gen 39 as representative of a male view:

The image of the vengeful and conniving woman scorned is an archetype more meaningful to men than to women, a means of asserting the male's desirability and innocence, projecting all sexual desire onto the woman, who is a manifestation of the feminine frightening to men. She is aggressive, independent,

9 Susan Eastman sees Paul's re-interpretation of the Sarah-Hagar story as exclusionary, noting further that, "The scandalous expulsion of the slave woman Hagar and her son Ishmael haunts interpretation of Abraham's family history in the late twentieth and early twenty-first centuries. The apostle Paul's 'allegorical' resignification of the birth narratives of Isaac and Ishmael, in Gal. 4.21-5.1, appears to intensify the scandal." Susan G. Eastman, "Cast Out the Slave Woman and her Son': The Dynamics of Exclusion and Inclusion in Galatians 4.30," Journal for the Study of the New Testament 28/3 (2006): 309-310.

10 Fretheim that Potiphar's wife was "the only woman given a role of consequence in the Joseph story" (Terence E. Fretheim, "The Book of Genesis: Introduction, Commentary and Reflections," in Introduction to the Pentateuch: Genesis, Exodus, Leviticus, Numbers and Deuteronomy (The NIBC Vol. II; ed. Leander E. Keck et al.; Nashville: Abingdon, 2015), 234. 
and sexually demanding. Such women never prosper in the Hebrew Scriptures. ${ }^{11}$

Niditch considers Potiphar's wife a powerful woman but notes that the culture of her day regarded "powerful women with suspicion as unnatural and evil." 12 It is, however, helpful to note here that the above feminine image is not the only one present in Genesis where women are also vulnerable to men's sexual advances and female sexuality is endangered, as in the case of Dinah (Gen 34) or Tamar (Gen 38), for example.

Although socio-economically privileged, Potiphar's wife is depicted in this Joseph narrative as a sensual, probably sex-starved, woman who would stoop low enough to solicit sex from her own servant. Her portrayal further highlights her negative characterisation as an adulteress and as a conniving and unconscionable liar who lay false charges against an innocent servant to cover her own wrongdoing. ${ }^{13}$ No one knows what happened to Potiphar after Joseph was imprisoned. One would expect that the one who went to prison would disappear from the narrative. Ironically, Potiphar's wife faded away from the story while the plot developed to magnify Joseph.

In addition to her socio-economic standing, Potiphar's wife appears to be a woman of great influence in her household. She exercised influence not only over the servants but also over her husband (Gen 39:13-19). She was so used to having her way around the house that the only person who dared to resist her eventually paid dearly for it. Therefore, Potiphar's wife had the last word in her case against Joseph, who soon headed to prison (Gen 39:19-20).

Compared to the story of Hagar, an Egyptian maidservant of Sarah, the ancestress of Joseph, it becomes ironic that Potiphar's wife became the Egyptian mistress of one of the descendants of Sarah. The sexual parallels in both narratives are also discernible. Whereas Hagar was forced to sleep with her mistress' husband, Potiphar's wife, an Egyptian, tried unsuccessfully to force her husband's servant to sleep with her. The outcomes of both sexual encounters were not pleasant, as Hagar was cast out into the desert and Joseph was cast into prison. However, Joseph's encounter with Potiphar's wife would not be the last with Egyptian women. He ended up with another Egyptian woman as his wife, as we shall see below.

1c Joseph's wife - Asenath, Daughter of Potiphera

With Joseph's release from prison and elevation to the highest office by Pharaoh, "Pharaoh... provides him a wife from the nobility, Asenath (i.e., she

11 Niditch, "Genesis," 44.

12 Ibid.

13 See Theodore Weinberger, "“And Joseph Slept with Potiphar's Wife': A Rereading," Literature and Theology 11/2 (1997): 145-151, for arguments that Joseph slept with Potiphar's wife. 
who belongs to the goddess Neith). She is the daughter of Potiphera (i.e., the one whom Re gave; probably identical in meaning to Potiphar, priest of On (i.e. Heliopolis), a prominent center for worship of the sun god Re." 14 One would agree with Fretheim that Asenath had a background of nobility. She was the daughter of an important priest, who is also mentioned by name in Gen 41:45, 50 and 46:20. There is an indication that giving a woman of nobility in marriage to a prominent man or to a man who had rendered a notable service was not uncommon in the ancient world (e.g. Jethro giving his daughter Zipporah to Moses in marriage in Exod 2:21 or the Pharaoh giving his sister-inlaw to Hadad the Edomite in $1 \mathrm{Kgs} \mathrm{11:19-20).} \mathrm{The} \mathrm{fact} \mathrm{that} \mathrm{the} \mathrm{Pharaoh}$ himself gave her to Joseph suggests that her family must have been closely linked to the king, which means that her high socio-economic status is not in doubt. The marriage to Joseph, the second-highest ruler in Egypt at that time, further conferred on her a high socio-economic status.

Curiously, however, Asenath is portrayed as a marginal character in the Joseph narrative. As the only other female character in the Joseph cycle and the only named female, one would expect that she also would have a voice like Potiphar's wife and that more would be revealed about her person. Regrettably, besides her status as a daughter, wife or mother, nothing else is said about Asenath, who remains in the background of Joseph's success story. Even in scenes where the reader would expect Asenath to feature, such as at dinner with Joseph's brothers or during Joseph and his sons' visit to his father, she remained invisible. Nonetheless, the irony should not be lost on the reader that whereas the accusation of an Egyptian woman sent Joseph to prison, an Egyptian woman was used to reward him after his release from prison. ${ }^{15}$ Unlike Potiphar's wife, who is portrayed as a brazen, lewd, conniving seductress, Asenath remains an undeveloped character in the story of Joseph - the silent, hidden trophy wife of the most powerful vizier in the Egypt of his time. One is also not clear about Asenath's religious life after her marriage to Joseph. Being the daughter of a known priest, did she continue to serve the gods of her father or did she join Joseph to serve the God of Israel? The answer may be uncertain but it seems clear enough that her sons were raised to follow the God of their father.

The Genesis account shows that the union between Asenath and Joseph produced two sons - Manasseh and Ephraim (41:51; 46:20). Subsequently, these two grandsons of Jacob were elevated to the status of sons by their grandfather Jacob (Gen 48:5-22). On a deeper level, the marital and reproductive ties between Hagar and Abraham and between Joseph and Asenath portend strong foundational ties between the descendants of Abraham and the Egyptians (read: Africans).

14 Fretheim, "The Book of Genesis," 242.

15 Niditch, "Genesis," 43, notes that Asenath was "part of the reward given to Joseph for successfully interpreting Pharaoh's dream..." 


\section{1d Shiphrah and Puah - Two Egyptian Midwives}

It is interesting to note that of the six female names found in the book of Exodus, ${ }^{16}$ three are clearly Israelite, namely Elisheba, wife of Aaron (6:23), Jochebed, mother of Aaron, Moses and Miriam (6:20) and Miriam, sister of Aaron and Moses $(15: 20,21)$ while Zipporah, the wife of Moses was a Midianite woman $(2: 21 ; 4: 25 ; 18: 2$; cf. 4:20; 18:6). However, the identity of the other two women, the midwives named Shiphrah and Puah (1:15), has been disputed. As Houtman has noted, "A disputed question is whether the midwives were Hebrew or Egyptian. The targums assume that they were Hebrew women. . ."17 In this essay, we accept Houtman's conclusion that "favour the view that Egyptian women are meant."18

When the Pharaoh who did not know Joseph (Exod 1:8) realised that the Israelites were multiplying too fast for his liking, he ordered the midwives to kill any baby boy born by a Hebrew woman and save only the girls. However, the two midwives sabotaged Pharaoh's plans by letting all the babies live (Exod 1:16-17). Some commentators have queried the fact that only two midwives are mentioned in the story, wondering how only two of them could cater to the needs of all the women of Egypt who gave birth. ${ }^{19}$ On the other hand, it has been argued that Shiphrah and Puah were probably the representatives or chiefs of the midwives. What is significant here is the easy access they had to the Pharaoh (Exod 1:15, 18), which implies they had some high degree of social ranking. These two women were professionals who stood out in their league and who were recognised by the palace.

Nevertheless, God also recognised these two women for their risk to save the Hebrew babies rather than kill them. God dealt well with the midwives and he decided to build them "houses" (Exod 1:20, 21). Propp says that the “"houses' are probably families." ${ }^{20}$ God built them homes.

\section{1e Pharaoh's Daughter - Moses' Adoptive Mother}

The appellation, Pharaoh's daughter, was used to refer to several women in the Old Testament. This will become clear subsequently in the discussion of

16 Cornelis Houtman, Exodus (Vol. 1; Historical Commentary on the Old Testament; Leuven: Peeters, 1993), 251.

17 Houtman, Exodus, 251. See however arguments for the opposing views in Nyasha Junior, "Exodus," in Women's Bible Commentary (Twentieth Anniversary Edition; ed. Carol A. Newsom, Sharon H. Ringe and Jacqueline E. Lapsley; Louisville: Westminster John Knox, 2012), 58.

18 Houtman, Exodus, 252.

19 Terence Fretheim, Exodus (Interpretation: A Bible Commentary for Teaching and Preaching; Louisville: John Knox Press, 1991), 31.

20 William H.C. Propp, Exodus 1-18: A New Translation with Introduction and Commentary (The Anchor Bible; Vol. 2; New York: Doubleday, 1999), 138, 141. Cf. NIV translation of phrase as God "gave them families of their own." 
African Women in the Nebiim. When Moses' mother could no longer hide him following the Pharaoh's edict that all the Hebrew baby boys be killed on the birthstone, she put him in an ark of the bulrushes which she placed by the river's brink, whilst his sister stood around to see what would become of the child (Exod 2:1-4). Then came with her retinue of maidens an unnamed Egyptian princess to the river to bathe. In the six verses that related the encounter by the river, this Egyptian princess was called Pharaoh's daughter (or the daughter of Pharaoh) five times. Perhaps the narrator thought stressing her royal status was better than calling her by her own name. No doubt, that royal status accorded her certain privileges and power, for instance, the liberty to defy her father's edict and save the little Hebrew child as well as the fact that she actually named and adopted him and later brought him to the palace to live with her, making Moses a bona fide Egyptian prince. She seemed to be able to do this without consulting her father.

This woman's position as the daughter of Pharaoh unmistakeably meant that she belonged in the highest socio-economic stratum of the society. She was a woman of means who had chaperones at her disposal (Exod 2:5) and had the financial freedom to pay for the services of a wet nurse for Baby Moses (Exod 2:9). Although her marital status was not stated in the text, the fact that she still lived in the palace and there was no mention of a husband or children could hint at spinsterhood. Nonetheless, she definitely was a woman of authority going by the way she issued instructions ${ }^{21}$ - she asked her maid to go and fetch the child, Moses' sister to go and get her a wet nurse and Moses' mother to take the child away to nurse him (Exod 2:5, 8, 9).

\section{1f Israelite Women's Egyptian Neighbours}

In addition to the named and unnamed individuals that we have examined above, the text also features women functioning together as members of the society in an ancient African setting. For example, in Exod 3:21-22, God had informed Moses that when it was time to depart Egypt, the Israelite women would not go out empty as they should borrow jewels of gold and of silver and clothing from their Egyptian neighbours (cf. Exod 11:2-3; 12:35-36). The items that the women were to borrow from their Egyptian counterparts show that these Egyptian women were wealthy, so wealthy that they were ready to forgo the borrowed items.

Sadly, these same women all lost their firstborn sons in the last plague that came upon Egypt on the night of Israel's deliverance. In their loss and grief, they would not have cared about gold and silver. ${ }^{22}$ Included also in the

21 Cf. the great woman of Shunem who issued instructions to both her husband and servants after her son died ( $2 \mathrm{Kgs} 4: 21-24)$.

22 One cannot but wonder what happened to the first-born children of Shiphrah and Puah on that night of the plague. Were they spared by the angel of death or did they 
women of the society in general would be the servants of Pharaoh's daughter who accompanied her and helped to draw baby Moses out of the river. These women served in the royal palace as servants but their status would no doubt be better than those of servants outside the palace.

\section{$1 \mathrm{~g}$ Moses' Ethiopian (Cushite) Wife}

Numbers 12:1-16 relates how Miriam and her Aaron complained against their brother Moses and the consequences of that action. The complaint was centred on Moses' Cushite or Ethiopian wife. ${ }^{23}$ However, some interpreters have questioned her African identity suggesting that she is the same person as Zipporah, making her Midianite rather than African. ${ }^{24}$ In this regard, Phyllis Trible asks an important question: "Whoever the woman is, is the attack racist, suggesting opposition to black Cushite skin?"25 This essay opts to answer this question in the affirmative. ${ }^{26}$ If this particular wife of Moses was the same as Zipporah or a Midianite woman, the text would have said so. ${ }^{27}$ Adamo unreservedly identifies the woman as "African" and regards the views that portray her as a Midianite or a member of a neighbouring tribe as "evidence of the de-Africanization of the Cushite woman by most Euro-American biblical scholars." 28

Interestingly, besides her nationality and marital status, nothing else is revealed about this woman, who was silent throughout the ordeal. She neither responded to Miriam and Aaron nor complained to Moses about their attitude towards her. Even though she remained in the shadows, there is no doubt that Yahweh favoured her. Yahweh did not seem to have a problem with Moses' marriage to a Cushite; actually, he punished Miriam for her role in the scene. ${ }^{29}$

die? Given that God "made them houses" (Exod 1:21), it would make sense to presuppose that these children were spared.

23 Whereas the KJV and the NKJV among others render the phrase as an Ethiopian woman, others such as the NIV, NASB or Good News call her the Cushite woman. The NET Bible however uses both saying, "Then Miriam and Aaron spoke against Moses because of the Cushite woman he had married (for he had married an Ethiopian woman)."

24 Cf. Olojẹde, "Miriam and Moses' Cushite Wife," 137, for a discussion.

25 Phyllis Trible, "Bringing Miriam out of the Shadows," in A Feminist Companion

to Exodus and Deuteronomy (FCB 6; ed. Athalya Brenner; Sheffield: Sheffield Academic, 1994), 175.

26 Cf. Funlọla Ọlọjẹde, "Miriam and Moses' Cushite Wife: Sisterhood in Jeopardy?" In Feminist Frameworks: Power, Ambiguity and Intersectionality (ed. Julia Claassens and Carolyn Sharp; London: Bloomsbury T\&T Clark, 2017), 133-145.

27 See Adamo, African and the Africans, 69-72, for a discussion of the different arguments regarding the identity of the Cushite wife of Moses.

28 Ibid., 70.

29 Ọlọjẹde, “Miriam and Moses' Cushite Wife," 138. 
The unnamed Ethiopian woman might have been despised because of her colour but she was married to Israel's No. 1 officer and ruler in terms of her socio-economic status. One also cannot but agree with Adamo that, "Although the Bible is silent concerning her contribution to the life of Moses, she likely held an important place in the leadership role of Moses." 30 Whether her mixed marriage contributed to her silence/silencing remains arguable. Although her status as a wife is clearly stated, her motherhood status is not mentioned, as there is no indication in the story or other texts that this Ethiopian woman bore any child for Moses.

\section{African Women in the Nebiim}

This section presents the named and unnamed women in the Nebiim who were of African origin.

\section{2a Daughters of Pharaoh-Solomon's Egyptian wife and Mered}

In the Old Testament story of the reign of Solomon, the reader is immediately confronted with the mention of Solomon's marriage to another unnamed daughter of the Pharaoh, mentioned four times in the text $(1 \mathrm{Kgs} 3: 1 ; 9: 16,24$; 2 Chron 8:11; cf. Exod 2:1-10). The marriage we are told cemented the political alliance between Solomon and the Pharaoh. Howard confirms that "Royal marriages were utilized to make political alliances in the ancient Near eastern world... The text provides no commentary to indicate that this move is unusual or problematic..." "31 However, Solomon's political alliance through marriage also resulted in strong economic ties between Israel and Egypt, as Egypt exported linen yarn, horses and chariots to Israel (1 Kgs 10:28-29; 2 Chron 1:16-17). It is striking that patriarchs gave only daughters in marriage in diplomatic arrangements; sons simply 'took' what they were given.

Although she is nameless in the text, this daughter of Pharaoh must have been quite a prize - the jewel of Solomon's eyes. Of Solomon's unprecedented number of wives and concubines, she is the first mentioned in the text, which suggests that she was probably his first and/or favourite wife. Furthermore, unlike other princesses from neighbouring nations (1 Kgs 11:3), she was the only woman Solomon built a separate house for which was comparable in glory to his own house (1 Kgs 7:8; 9:24). ${ }^{32}$ It was the least Solomon could do; for this rich princess already had a good endowment from a doting father who conquered Gezer and gave the city to her as a present (1 Kgs 9:16). Her father destroyed the city before giving it to her though; it was Solomon who rebuilt it

30 Adamo, African and the Africans, 73.

31 Cameron B.R. Howard, "1 and 2 Kings," in Women's Bible Commentary (Twentieth Anniversary Edition; ed. Carol A. Newsom, Sharon H. Ringe and Jacqueline E. Lapsley; Louisville: Westminster John Knox, 2012), 169.

32 Note that earlier Solomon had brought her with him to the city of David before he built his own palace (1 Kgs 3:1). 
(1 Kgs 9:15, 17). This Egyptian princess and Israel's queen was not your regular 'housewife'; she was high-maintenance. Rather than being seen as a victim of patriarchy, it seems this daughter of Pharaoh had the men in her life at her beck and call.

Remarkably also, whereas the text acknowledges that Solomon's numerous wives and concubines enticed his heart to serve their gods and goddesses - Ashtoreth the goddess of the Sidonians, Milcom and Molech the gods of the Ammonites, Chemosh the god of the Moabites (1 Kgs 11:5, 7, 33)there is no indication that he sacrificed to the gods of his Egyptian queen. In fact, it seems he distanced himself from her gods, for he moved her out of the city of David to the house he had built for her, saying, "My wife shall not dwell in the house of David king of Israel, because the places are holy, whereunto the ark of the Lord hath come" (2 Chron 8:11b).

Besides Solomon's wife and the unnamed daughter of Pharaoh in Exod 2, the Old Testament text features another daughter of a Pharaoh who is the only named Pharaoh's daughter in the text. She is called Bithiah, one of the wives of Mered, a Judahite (1 Chron 4:18). Not much is known about Bithiah besides that she was in a polygamous marriage and bore sons. Like many women of her time, she also was "taken." Mered took her from her father, who gave her out like a commodity. The social status of Mered can only be inferred - if he qualified to take a Pharaoh's daughter, he must have had a high standing in the society. Bithiah, his wife and a Pharaoh's daughter, would therefore be a woman of some means.

\section{2b The Queen of Sheba}

The story of the Queen of Sheba and her visit to King Solomon is told in $1 \mathrm{Kgs}$ 10:1-13//2 Chron 9:1-12. She travelled up with a very large train to visit Solomon and test him with hard questions (1 Kgs 10:1). However, commentators argue that besides her questions, another possible reason for the journey could have been to establish or "strengthen trade relations" with Israel. ${ }^{33}$ Adamo affirms that the queen's visit must have been "multipurpose," including establishing a close personal relationship with Solomon. ${ }^{34}$ In contrast, Howard notes that exchanging gifts between the two royals "implies a political alliance (accomplished with a woman, yet without marriage)." ${ }^{35}$ Although the specific location of Sheba has been queried by different scholars, many (including Adamo) ${ }^{36}$ agree that it is used in reference to Ethiopia here. ${ }^{37}$

33 Stephen D. Ricks, "Sheba: Queen of," in $A B D$ (Vol. 5, O-Sh; ed. David Noel Freedman et al; New York: Doubleday, 1992), 1170.

34 Adamo, African and the Africans, 92-93.

35 Howard, "1 and 2 Kings," 164.

36 Adamo, African and the Africans, 87-94. 
Josephus also links her with Ethiopia. ${ }^{38}$ In Matt 12:42, Jesus refers to the queen as the Queen of the South and that she came from the "uttermost parts of the earth," suggesting a further distance from Israel than a location in modern day Yemen.

For Adamo, the Queen of Sheba was no mere queen; she was an African queen, considering that the story of the Queen of Sheba's visit to King Solomon is found in the Islamic, Jewish and Ethiopian traditions. ${ }^{39}$ Adamo also offers a brief review of some studies that consider the story of the queen's visit to Solomon a legend and of those that see it as historical. Adamo, however, subscribes to the view that there are some elements of historicity in the story. ${ }^{40}$

There is no doubt that this Queen of Sheba ruled over a sophisticated kingdom ${ }^{41}$ and that she must have been a figure of international repute in terms of politics and trade/economy, else, she would not have had access to a renowned king like Solomon. The fact that her visit was considered important enough to feature in Israel's theological archives attests to her calibre and status in the ancient world. It is also striking that the Queen of Sheba could not be muted. She was a woman with a voice. Her speech, which was in praise of King Solomon, was recorded in the holy writ. Equally remarkable are her economic status and prowess. When the queen visited King Solomon, she came with an entourage of many servants and valuable items such as gold, precious stones and spices that she gave to Solomon (1 Kgs 10:2, 10). By any standard, this was a very wealthy queen from a wealthy nation, a woman of class. To be sure, the Queen of Sheba was a woman of power and authority who ruled over a powerful nation with servants (read: men) at her command. She could hold out her own with great men, even those as intellectually endowed as Solomon (1 Kgs 10:1). It is unsurprising then that Howard remarks that, "The queen's visit mitigates the portrait of foreign women in Kings, inverting the seduction usually enacted by foreign women onto Israelite men." 42 The status and

37 Some scholars have located Sheba in the South West corner of the Arabian Peninsula from where some merchants traded with ancient Israel (cf. Ps 72:15; Isa 60:6; Ezek 27:22; cf. 38:13). However, in the Kebra Nagast, which is Ethiopia's national saga, the story is told of the Queen's visit to Solomon which resulted in her conversion to Judaism and in the birth of a son to Solomon called Menelik. Cf. Ricks, "Sheba: Queen of," 1171. Note that Cogan locates Sheba in modern day Yemen. Mordechai Cogan, 1 Kings: A New Translation with Introduction and Commentary (The Anchor Bible; New York: Doubleday, 2000), 310-311.

38 See discussion in Adamo, African and the Africans, 91.

39 Ibid., 87-88.

40 Ibid., 89-90.

41 Other powerful queens must have come out of that region in antiquity as the presence of another female ruler, Candace queen of the Ethiopians (i.e. royal Queen Mother of Nubia) in Acts 8:27 suggests. The Ethiopian Eunuch was described as a top official under her administration.

42 Howard, "1 and 2 Kings," 168. 
accomplishments of the Queen of Sheba were not based on her sexuality or physical beauty or supposedly on her ability to seduce men. She was an accomplished woman in her own right $!^{43}$

Unquestionably, the Queen of Sheba belonged in the topmost cadre of societal rankings of her time, whether locally or internationally. The presence of an eminent female figure such as the Queen of Sheba in the annals of ancient Israel therefore serves as an encouragement to African women today who more often than not succumb to the limitations imposed by the norms of their patriarchal context. African women have the right to ascend loftiest positions in society in local or limited spaces and on the international scene. Women such as former Liberian President Ellen Johnson Sirleaf and Nigerian economist Ngozi Okonjo-Iweala, the Director-General of the World Trade Organization, have proven in recent years that women have a place.

\section{2c Mrs Jeroboam and Mrs Hadad (Egyptian Wives of Solomon's}

Adversaries) and Queen Tahpenes

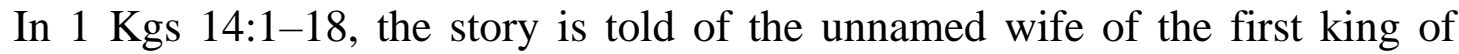
Divided Israel's Northern Kingdom whose child Abijah fell sick. King Jeroboam asked his wife to disguise as another woman and take presents to Ahijah the prophet to enquire about the fate of the sick prince. Before she got to Ahijah in Shiloh, however, God had told the blind Ahijah not only of her ruse and mission but also that the child would die. When the queen then arrived at Ahijah's, the prophet smoked her out and confronted her with her husband's wrongdoings and the news of God's impending judgment against him and his household. As soon as she returned to her city, the child died according to the word of the man of God. ${ }^{44}$

It is interesting that this woman never uttered a word in the 1 Kings account of the errand she ran for her husband. Only the speeches of the two male characters are featured in the story. Jeroboam issued instructions to her, which were reported in direct speech. Ahijah's utterances are also on record but

43 Maria Häusl offers an interesting remark that in the Old Testament, the designations שלכה (queen) שרה (female ruler) שרה (fuenale ruler) are used for foreign royal women "but hardly in reference to wives of Israelite kings... No woman from neither the Judean nor Israelite royal house is designated as מלכה, "queen," not even Jezebel, who governed together with her husband, Ahab... Only women at foreign royal courts are designated as מלכה for example, the queen of Sheba and Vashti, the queen at the Persian court in the book of Esther." Maria Häusl, "Women at the King's Court: Their Political, Economic, and Religious Significance in the Accounts of the Former Prophets," in Prophecy and Gender in the Hebrew Bible (The Bible and Women: An Encyclopedia of Exegesis and Cultural History; ed. L. Juliana Claassens and Irmtraud Fischer; Atlanta: SBL Press, 2021), 229-252 (241242).

44 Howard, "1 and 2 Kings," 170-171. 
not her response. Did she plead with Ahijah to pray for mercy for the child? Not one word is attributed to this silent queen who served only as a messenger of two powerful men - and, indirectly, of God.

Although the MT does not mention Jeroboam's wife by name, the LXX B does. She is called Ano, the older daughter of Pharaoh Susakim (Shishak) and his wife Kimmina and she became the mother of Abijah, the prince ( $3 \mathrm{Kgs}$ 12:24, NRSV [LXX]). Following the LXX rendering, Adamo demonstrates that Jeroboam's wife, who was not just nameless but also voiceless in the MT, had her origin in Africa. ${ }^{45}$ Not only that, her silence in the narrative has literary significance. Adamo writes:

The silence of the wife of Jeroboam sheds light on the prophet Ahijah's and Jeroboam's character. Jeroboam shows a manipulative character. The theme of obedience which the silence of Jeroboam's wife demonstrates is an important one in Jeroboam's cycle. The silent and unnamed woman/wife of Jeroboam obeys her husband and the prophet Ahijah without question and returns home while many modern women would have disobeyed the prophet's instruction with the possibility of saving her son. ${ }^{46}$

Adamo further considers the queen's silence a sign of humility and wisdom. However, in the patriarchal context of ancient Israel, is it possible that her silence was induced by the patriarchal norms of her day and sealed by the narrator? Regardless of her silence (and namelessness in the MT), Ano was no commoner but a woman of high socio-economic standing and class. As a queen and the mother of a prince (or princes), she was already highly placed; but she did not attain that high class through her marriage to King Jeroboam. As a princess of Egypt, she was born royalty. Her willingness to disguise at her husband's behest possibly also points to her understanding of royal protocols and covert (undercover) operations. Her husband might have been a bully, ${ }^{47}$ but he trusted her with a delicate and secret mission. The fact that she was able to travel freely between cities without the presence of her husband also indicates some degree of agency and freedom in the public arena that contrasts with images of ancient women as those confined to harems and the private sphere. Even though Queen Ano did not speak in the narrative, her actions spoke volumes - about her quiet grace, compassion, complicity and readiness to accept what she could not change.

In a sense, the marriage of the fugitive Jeroboam to an unnamed princess in the Egyptian royal house is a striking parallel to that of another nameless

45 David Tuesday Adamo, "The Unheard Voices in the Hebrew Bible: The Nameless and Silent Wife of Jeroboam (1 Kgs 14:1-18)," OTE 33/3 (2020): 399-402; Cf. Idem, "The African Wife of Jeroboam," Theologia Viatorum 37/2 (2013): 71-89.

46 Adamo, "The Unheard Voices," 403.

47 Ibid., 405. 
woman in $1 \mathrm{Kings,}$ the wife of Hadad an Edomite. Like Jeroboam, Hadad, an Edomite prince, an adversary of King David, fled to Egypt and, while in Egypt, the Pharaoh gave him as a wife, the sister of his wife, Tahpenes. Hadad and his nameless Egyptian wife had a son named Genubath, who grew up in the palace among the princes of Pharaoh. To the modern reader, the freedom of Pharaoh to decide whom his sister-in-law married would be considered absurd given that he was not even the woman's father. However, in the world of the Pharaohs, taking or giving out a woman was not a big deal. After all, a Pharaoh took Sarai (Gen 12:10-20), while another Pharaoh gave Asenath to Joseph and yet another Pharaoh his daughter to be taken by Solomon (1 Kgs 3:1). The wife of Hadad, without doubt, would be regarded as nobility, considering that her sister married the most powerful man in the land of Egypt and that her husband was in political exile and an ally of the Pharaoh. It is not clear if Hadad's wife remained in Egypt with her son or followed her husband to Edom after he learnt that David had died (1 Kgs 11:21-22).

As already noted, another Egyptian woman who features in the wife of Hadad's story is her sister, Queen Tahpenes, the wife of the Pharaoh. Tahpenes appears to wield some strong influence in the palace, given that her married sister continued to live in the palace where her nephew Genubath was born, weaned and raised like her own sons. Unlike her unnamed sister, though, Tahpenes' was identified by name, but surprisingly, her husband was not (1 Kgs 11:19-20). ${ }^{48}$ Her socio-economic status would also be commensurate with that of women of her calibre.

\section{SUMMARY AND CONCLUSION}

This essay has considered the characterisation of women of ancient "African" origin in the Torah and in the Nebiim. In the Torah, noticeable is the story of Hagar, whose status experienced twists and turns. Hagar started as the Egyptian slave of Sarai and moved from being a slave to becoming the wife of Abram alongside Sarai but she was downgraded to a desert wanderer when Abram and Sarai sent her away. Other African women of high status include the unnamed wife of Potiphar, Asenath (the daughter of an Egyptian priest and the wife of Joseph), Pharaoh's daughter who became 'the adoptive mother' of Moses, the midwives, Puah and Shiphrah for whom God built families and Moses' Cushite wife.

In the Nebiim, all the women are presented as married and of high socio-economic status. Two separate daughters of Pharaoh are mentioned who

48 Park, Hye Kyung, "Why Not Her? Form Critical Interpretation of the Named and Unnamed Women in the Elijah and Elisha Traditions" (PhD diss., The Claremont Graduate University, 2011), 2 fn.2, lists Tahpenes and her sister, Hadad's wife, respectively among the named and unnamed women in the Elijah and Elisha traditions. 
were married to Israelite men, that is, to King Solomon and to Mered. The Queen of Sheba is clearly at the top of the pack - a woman of authority and power and of international repute. Jeroboam's wife and Hadad's wife were Egyptian women married to two main adversaries of Solomon. The latter was given to Hadad by the Pharaoh who himself was married to Queen Tahpenes, Hadad's wife's sister. However, beyond the image of woman as wife or mother, the presence of characters such as Pharaoh's daughter (Exod 2) and Queen of Sheba (1 Kgs 10) in the text demonstrates that women exercised influence in their own right.

The high status of the majority of the women of African descent in the Torah and Nebiim seems to invalidate the assumption that women in the ancient world were victims of patriarchy or that African cultures subjugate women under the guise of patriarchy. As the foregoing review shows, these African women were no base characters but women of substance and worth. Several were princesses, wives of kings or nobles and one a ruling queen over her nation. Did these women then act in the interest of patriarchy? Not at all. In fact, women such as Shiphrah and Puah and the Pharaoh's daughter in Exod 2, who acted to subvert the dictates of patriarchy, confirm that women exercised agency, even if they had to resort to trickery at times. ${ }^{49}$

Of course, one could say that the text itself was selective in terms of the characters of women that it features. Be that as it may, the real issue here is that the status of most of these women points to a high degree of socio-economic independence and freedom that many African women are denied in the name of patriarchy.

Therefore, from a gender and feminist perspective, this essay complements Adamo's works that highlight the presence of Africa and Africans in the Bible.

\section{BIBLIOGRAPHY}

Adamo, David T. Africa and Africans in the Old Testament. Eugene: Wipf and Stock, 2001.

. Exploration in African Biblical Studies. Eugene: Wipf and Stock, 2001.

."The African Wife of Jeroboam." Theologia Viatorum 37/2 (2013): 71-89.

. "The Unheard Voices in the Hebrew Bible: The Nameless and Silent Wife of Jeroboam (1 Kgs 14:1-18)." Old Testament Essays 33/3 (2020): 393-407.

. "Reading Jeremiah 13:23 in an African Context." Journal for Semitics 23/2 (2014): 500-530.

"The Portrayal of Africa and Africans in the Book of Jeremiah." In die Skriflig 51/1, (2018) a2259. DOI: https://doi. org/10.4102/ids.v51i1.2259, 2018.

49 For a classic discussion of the use of trickery by women in the Hebrew Bible, see Susan Niditch, Underdogs and Tricksters: A Prelude to Biblical Folklore (New Voices in Biblical Studies; New York: Harper \& Row, 1985). 
Cogan, Mordechai. 1 Kings: A New Translation with Introduction and Commentary. The Anchor Bible. New York: Doubleday, 2000.

Eastman, Susan G. "“Cast Out the Slave Woman and her Son': The Dynamics of Exclusion and Inclusion in Galatians 4.30." Journal for the Study of the New Testament 28/3 (2006): 309-336.

Fretheim, Terence E. Exodus. Interpretation: A Bible Commentary for Teaching and Preaching. Louisville: John Knox Press, 1991.

. "The Book of Genesis: Introduction, Commentary and Reflections." Pages 17-276 in Introduction to the Pentateuch: Genesis, Exodus, Leviticus, Numbers and Deuteronomy. The NIBC Vol. II. Edited by Leander E. Keck et al. Nashville: Abingdon, 2015.

Häusl, Maria. "Women at the King's Court: Their Political, Economic, and Religious Significance in the Accounts of the Former Prophets." Pages 229-252 in Prophecy and Gender in the Hebrew Bible. The Bible and Women: An Encyclopedia of Exegesis and Cultural History. Edited by L. Juliana Claassens and Irmtraud Fischer. Atlanta: SBL Press, 2021.

Houtman, Cornelis. Exodus. Vol. 1. Historical Commentary on the Old Testament. Leuven: Peeters, 1993.

Howard, Cameron B.R. "1 and 2 Kings." Pages 165-183 in Women's Bible Commentary. Twentieth Anniversary Edition. Edited by Carol A. Newsom, Sharon H. Ringe and Jacqueline E. Lapsley. Louisville: Westminster John Knox, 2012.

Junior, Nyasha. "Exodus." Pages 56-69 in Women's Bible Commentary. Twentieth Anniversary Edition. Edited by Carol A. Newsom, Sharon H. Ringe and Jacqueline E. Lapsley. Louisville: Westminster John Knox, 2012.

Niditch, Susan. Underdogs and Tricksters: A Prelude to Biblical Folklore. New Voices in Biblical Studies. New York: Harper \& Row, 1985.

. "Genesis." Pages 27-45 in Women's Bible Commentary. Twentieth Anniversary Edition. Edited by Carol A. Newsom, Sharon H. Ringe and Jacqueline E. Lapsley. Louisville: Westminster John Knox, 2012.

Ọlọjẹde, Funlọla. “Miriam and Moses' Cushite Wife: Sisterhood in Jeopardy?” Pages 133-145 in Feminist Frameworks: Power, Ambiguity and Intersectionality. Edited by Julia Claassens and Carolyn Sharp. London: Bloomsbury T\&T Clark, 2017.

Pigott, Susan M. "Hagar: The M/Other Matriarch." Review and Expositor 115/4 (2018): 513-528.

Propp, William H.C. Exodus 1-18: A New Translation with Introduction and Commentary. The Anchor Bible Vol. 2. New York: Doubleday, 1999.

Ricks, Stephen D. "Sheba: Queen of." Pages 1170-1171 in The Anchor Bible Dictionary. Volume 5 (O-Sh). Edited by David Noel Freedman et al. New York: Doubleday, 1992.

Trible, Phyllis. "Bringing Miriam out of the Shadows." Pages166-186 in A Feminist Companion to Exodus and Deuteronomy FCB 6. Edited by Athalya Brenner. Sheffield: Sheffield Academic, 1994.

Weinberger, Theodore. "'And Joseph Slept with Potiphar's Wife': A Re-reading." Literature and Theology 11/2 (1997): 145- 151.

Yoo, Philip Y. "Hagar the Egyptian: Wife, Handmaid, and Concubine." The Catholic Biblical Quarterly 78/2 (2016): 215-235. 
Dr Funlọla O. Ọlọjẹde, Gender Unit, Beyers Naudé Centre for Public Theology, Stellenbosch University. Email: funlola@sun.ac.za. ORCID: https://orcid.org/0000-0002-5991-9308 